\begin{tabular}{|l|l|}
\hline Postprint Version & 1.0 \\
\hline Journal website & http://www.springerlink.com/content/00177585g3557856/ \\
\hline Pubmed link & \\
\hline DOI & $10.1007 /$ s12483-011-0047-z \\
\hline
\end{tabular}

This is a NIVEL certified Post Print, more info at http://www.nivel.eu

\title{
Website met informatie-op-maat blijkt goede voorbereiding op erfelijkheidsonderzoek voor borstkanker.
}

Promotiedatum: 27 april 2011 Naam promovendus: Akke Albada Universiteit: Universiteit Utrecht Onderzoek uitgevoerd: NIVEL (Nederlands instituut voor onderzoek van de gezondheidszorg) en Afdeling Medische Genetica UMC Utrecht Titel van het proefschrift: Preparing for breast cancer genetic counselling, webbased education for counselees Vrouwen die willen weten of de borstkanker bij henzelf of in hun familie erfelijk is, kunnen na verwijzing een afspraak maken voor erfelijkheidsonderzoek. Ze weten echter vaak niet wat ze daarvan kunnen verwachten of hebben onrealistische verwachtingen.

Ze verwachten bijvoorbeeld dat er altijd een DNA-test wordt gedaan en dat een testuitslag zekerheid geeft. Ook beseffen adviesvragers soms niet dat voor erfelijkheidsonderzoek medische informatie van aangedane familieleden nodig is en dat de uitslag ook gevolgen heeft voor hun familie.

In het eerste gesprek voor erfelijkheidsonderzoek bespreekt de klinisch geneticus of genetisch consulent op basis van de familiestamboom of er aanwijzingen zijn voor erfelijke borstkanker en of er een indicatie is voor DNA-onderzoek. De adviesgever geeft doorgaans veel informatie tijdens dit gesprek, onder andere over erfelijke borstkanker en wat het betekent om drager te zijn van een erfelijke aanleg. Uit eerder onderzoek van het NIVEL en UMC Utrecht blijkt dat adviesvragers over het algemeen zelf weinig inbrengen tijdens het gesprek en dat ze maar de helft van de informatie onthouden.

Omadviesvragers beter voor te bereiden op erfelijkheidsonderzoek ontwikkelden het NIVEL en het UMC Utrecht met subsidie van KWF Kankerbestrijding de educatieve website E-info gene ${ }^{\text {ca }}$. De informatie die adviesvragers op de website te zien krijgen is toegesneden op hun persoonlijke medische voorgeschiedenis en medische familiegeschiedenis.

Daarnaast biedt de site een lijst om vragen voor het gesprek op te schrijven. Onderzocht werd of adviesvragers door de website andere verwachtingen kregen en of het eerste gesprek meer patiëntgericht verliep. Hiervoor kregen 100 adviesvragers toegang tot de website. De controlegroep (100 andere adviesvragers) kreeg geen toegang. Voor dit onderzoek werden vragenlijsten voor en na het eerste gesprek en op video opgenomen consulten geanalyseerd.

$\mathrm{Na}$ het lezen van de informatie op de website hadden adviesvragers realistischere verwachtingen van erfelijkheidsonderzoek.

Ze haalden ook meer uit het gesprek door zich actiever op te stellen. Ze vertelden bijvoorbeeld meer over de reden voor hun ongerustheid, brachten meer onderwerpen in en checkten vaker of ze de informatie goed begrepen. Adviesvragers die zich hadden voorbereid met de website toonden ook minder onbegrip wanneer er geen indicatie was voor een DNA-test. Doordat de vragen van de adviesvragers vanaf de website naar de geneticus of consulent waren gestuurd, stonden deze meer centraal in het gesprek.

Vrouwen in de interventiegroep onthielden meer van het eerste gesprek vergeleken met de controlegroep; ze hadden daarna ook meer kennis over erfelijke borstkanker en vonden dat er beter aan hun informatiebehoefte tegemoet was gekomen. Deze effecten waren het meest duidelijk bij vrouwen die geen indicatie voor een DNA-test kregen en die dus ook niet voor een tweede gesprek uitgenodigd werden. Bij deze groep vrouwen was de angst ook meer afgenomen in de interventiegroep dan in de controlegroep.

Dit is een belangrijke bevinding, omdat adviesvragers zich vaak veel zorgen blijven maken over hun kans op borstkanker.

De groep vrouwen die geen indicatie krijgt voor DNA-onderzoek heeft geen wezenlijk verhoogd risico op borstkanker en de afname in angst is dus een heel wenselijk effect.

Een website met informatie-op-maat blijkt een goede voorbereiding op erfelijkheidsonderzoek voor borstkanker. De bedoeling is om deze website in de dagelijkse praktijk te gaan implementeren en voor een bredere groep adviesvragers beschikbaar te maken. 